\title{
Portrayal of Psychic Violence in \\ Fire on the Mountain and The Bluest Eye
}

\begin{abstract}
AROOP SAHA
Abstract

The role of woman is significant in the human world from the ancient time not only as a human being but also as an inseparable entity to take the mankind ahead with the time. The woman represents the symbol of nurture. She contributes to make progress in the family, society as well as country through her active participation same as the male counterpart. But woman is suppressed into lower status compared to the male power and position in the society intentionally, even after her great contribution in reality. The evidence can be found in the portrayal of woman in the literatures from the different cultures. How does the patriarchal society suppress the woman? How is the patriarchal ideology dominating the grand-narrative as well as molding the notion of woman's psychology? In what ways, the voice of woman is controlled and represented with manipulative hegemony in unconstructive words? How is the woman fighting against the psychic violence to construct her self? Anita Desai's Fire on the Mountain and Toni Morrison's The Bluest Eyes echo those thought provoking questions with ravenous eyes to discover the real female subject. Both writers exhibit the woman's situation, emotion and realization which are scrutinized to observe the universality of female psyche.
\end{abstract}

It was all a lie, all. She had lied to Raka, lied about everything. Her father had never been to Tibet . . Nor had her husband loved and cherished her and kept her like a queen - he had only done enough to keep her quiet while he carried on a lifelong affair with Miss David, the mathematics mistress, whom he had not married because she was a Christian but whom he had loved, all his life loved. And her children - the children were all alien to her nature. She did not live here alone by choice - she lived here alone because that was what she was forced to do, reduced to doing. All those graces and glories with which she had tried to captivate Raka were only a fabrication: They helped her to sleep at night, they were 
tranquillizers, pills. She had lied to Raka. And Ila had lied, too. Ila, too, had lied, and tried.

\section{- Anita Desai, Fire on the Mountain 145}

They never seem to have boyfriends, but they always marry. Certain men watch them, without seeming to, and know that if such a girl is in his house, he will sleep on sheets boiled white, hung out to dry on juniper bushes, and pressed flat with a heavy iron. There will be pretty paper flowers decorating the picture of his mother, a large Bible in the front room. They feel secure. They know their work clothes will be mended, washed, and ironed on Monday ... Her hips assure them that she will bear children easily and painlessly. And they are right. . . But the men do not know these things. Nor do they know that she will give him her body sparingly and partially. He must enter her surreptitiously, lifting the hem of her nightgown only to her navel. He must rest his weight on his elbows when they make love, ostensibly to avoid hurting her breasts but actually to keep her from having to touch or feel too much of him.

\section{- Tony Morrison, The Bluest Eye 65}

Since the ancient time, woman is portrayed as a fragile figure both for her psyche and physic in arts and literatures of the world. The image of the woman is constructed in such a way as if she depends on man for revealing her own self. Vicariously, the patriarchal exhibition shows the woman either as an angel or as an evil. This undeniable and intentional representation does not picture the real human woman. The patriarchal grand-narrative has transformed the female character into a commodity or an object which can be suppressed. Intentionally, it is exhibited that the position of woman in the society is below the position of man. She is kept beneath the strong influence of male domination. But the most interesting part is that the patriarchal society or ideology glorifies the repressed female as a humble, devoted, docile, and naive subject. She does not get approval from the male dominated society to construct her own subjectivity and identity by herself. She is dominated continuously by the notions and ideologies of the patriarchy directly and indirectly. The voice of female subject is represented by the 
male voice. This diversion of representation provokes the doubt of actual voice of female psyche. So the question can be asked, who is representing whom? How are the females dominated by the patriarchal society with ideology? In which process is their construction of subject troubled? Are the women resisting this subjugation or they are submitting themselves before the patriarchy? These controversial issues are echoed in literatures of different locations around the world in different times. Even though languages, cultures, life-styles, skin-colours, locations and environments are different from each other, those different literatures reflect the common issues of psychological and physical suppression on the females by the male dominated societies. The condition of female position in different literatures is almost similar. For instance, if we concentrate on the construction and condition of African-American as well as Indian female subjects, we shall discover the similarity in experience and realization despite their diversified cultures and environments. The renowned Indian novelist Anita Desai's Fire on the Mountain and the famous African-American writer Tony Morrison's The Bluest Eyes present us a glimpse of those burning issues regarding female's struggle to survive with her own existence and identity. Both the writers indicate the pendulum situation of woman who is in between hope and despair. This paper will investigate the portrayal of female psyches which are represented from different locations and generations with the intention to excavate the struggle to construct the strong female subject with fervent voice out of fragile existence and how this exertion of the two different continents' writers has turned out to be universal which leads the readers to a universal struggle of female subject with perplexed psyche.

Feminists of different countries through their writing investigate these issues of suppression, realization and struggle of female as individual and society. They have begun to navigate that approach in the late-twentieth century although the expedition of constructing female identity is on its way in early twentieth century. The crucial motive of the feminists is to discover the treatment of writers and intellectuals on the process of constructing female subject and ideology in the society as well as in literature. And the significant innovation is that through the eyes of the patriarchal ideology, the woman is portrayed either as a character of heaven or evil instead of showing her as a human being in flesh and blood. Even it 
is significant to note that even the female writers have preferred to represent the women in favour of patriarchal notions besides the male writers. For instance, a lot of female writers like Jane Austen and Charlotte Brontë, wrote novels, essays, poems and stories and their writings exhibit the women from the patriarchal point of view. One can raise questions: Why did those writers do that? What were the reasons? Were those exhibitions intentional? The chief reason is - those female writers were trained up by the stream of patriarchal ideologies. Their writings do not reflect actual scenario of the female. As Toril Moi in her essay 'Feminist, Female, Feminine', states ". . . it still needs to be said that not all books written by women on men writers exemplify anti-patriarchal commitment. . . . A female tradition in literature or criticism is not necessarily a feminist one" (246). Interestingly, those writers may be influenced by the patriarchy but they sometimes give few glimpses on the female's captive situation or lack of freedom to choose her own destination. The feminists fight against the patriarchy's mindset and system. Some can ask the question or argue about the authenticity of the portrayal of women in literature. But it is true that literature is the mirror of the culture and society. Whatever happens in the society, the writers of a particular era reflect those elements in their writings. That is how, we, the readers find the ideology as well as the attitude towards women from the texts. From 1960, western feminist critics have started to examine literature written by both male and female writers to see how the female characters are portrayed. At first the feminist critics have tried to find out the patriarchal domination on the women as well as the representation of the women in various written documents, stories, novels, poems and plays. They attempt to accumulate the evidences. ". . . women writers searched for a language of their own, a style, a voice, and a structure with which they could enter a discipline previously dominated by men" (Coward 4). In the 1970s, the intention of the feminist critics is changed. With the help of those evidences discovered in the first phase, they create new narratives with new perspectives. In this second phase, they endeavour to define female self. At the same time, it ". . . defines and traces the connections throughout history and across national boundaries of the recurring images, themes, and plots that emerge from women's social, psychological, and aesthetic experience in male-dominated cultures" (6). To construct the female subjectivity, the feminist 
critics discover the necessity of theory and ideologies in the 1980s to strengthen the power and status of women in the world of patriarchy.

In its third phase, . . f feminist criticism demanded not just the recognition of women's writing but a radical rethinking of the conceptual grounds of literary study, a revision of the accepted theoretical assumptions about reading and writing that have been based entirely on male literary experiences. (8)

Interestingly, the two novels - Anita Desai's Fire on the Mountain (1977) and Tony Morrison's The Bluest Eye (1979), through which we will analyze the psychic violence in the female character, are published at the end of second phases. It can also be said that the content of the stories and time of the writings of the novels cover the first and second phases where Anita Desai and Toni Morrison like the feminist critics try to find the position of woman and struggle to build the female subjectivity in their respective location and culture. Although the two novels deal with different continents, contexts and experiences, the main common issue is that both share the same kind of individual female experiences in the male dominated societies. It is evident that Morrison's The Bluest Eye shows more intensive violence of psychology through the character of Pecola and Pauline than Desai's Fire on the Mountain which focuses on an old woman, Nanda Kaul living in Carignano, India. Nanda Kaul's life is full of isolation. In The Bluest Eye, Pecola and Pauline are daughter and mother in relation. Although there is a generation gap between the mother and the daughter, both of them go through the typical Black American woman's growth where physical and sexual humiliation by the male, psychological deformity, falsehood, pretension, domination, fascination for the white beauty, selfconflict, internalized alienation and identity crisis for being woman are obviously touched. The American Black slave history is also in the background which creates resonance to the present Black womanhood. On the other hand, Nanda Kaul also faces the traditional Indian patriarchal domination. She talks little and her unwillingness to keep in touch with her known relatives reveals her intention of escapism. Even she expresses her uneasiness and inability to connect to the different generation when her great grand daughter Raka comes in Carignano for recovering from typhoid. "She wanted no one and nothing else. Whatever else came, or happened here, would be an unwelcome intrusion and distraction. . . All 
she wanted was to be alone, to have Carignano to herself, in this period of her life when stillness and calm were all that she wished to entertain" (Anita 3-17). There is a similarity between Nanda Kaul and Raka. They both want to keep themselves isolated from each other and society. Raka and Nanda Kaul represent respectively the very young generation and the very old generation of the Indian female world. This generation gap can be seen as the two different times of the world. Raka may symbolize the modern generation female subject of India. Similarly, Nanda Kaul may signify the old and colonial generation's female self of India. Interestingly, both the novels' protagonists are females and they exhibit their experience, history and present status in the societies although the contexts, cultures and situations of the two novels are situated in two different poles of the world.

Anita Desai's Fire on the Mountain portrays the pangs and agony of an old woman, Nanda Kaul. But we, the readers do not get the real picture of Nanda Kaul's actual struggle to live in this world until we reach the last few pages of the novel. The whole story gives an indication of her unhappiness and detachment from surrounding. Anita Desai creates a false and superficial cloud over the main story skillfully. This cloud hides the Indian woman's captive psychological and physical condition from the attention of the readers. The stylistic and content diversity create layers of meanings and metaphors. The suppression of the suffering of a middle class Indian woman is reflected by evading the main story. Similar to this argument is Amar Nath Prasad's thought provoking questions regarding the portrayal of women by the women novelists in his essay 'A Brief History of Indian Women Novelists in English':

Now the question is: Why is it that women novelists portray mostly the miserable life of an average Indian women? Why is it that a woman has to suffer insult and abuse, tyranny and injustice without any rhyme and reason in this male-dominated societal framework? (2)

The questions are relevant for Desai's Fire on the Mountain. Although it is not clear whether Nanda Kaul is from the upper class or from the middle class, her lifestyle and attitude reveal her social class status. She is like the other average Indian women who are always expected to be devoted, docile and responsible 
traditional women. The conventional ideology of Indian culture is that the women's position should be inferior compared to men. Here, the women's physic and psyche, both are dominated by the institutions' societal structure. For example, social value, religion, education and myth are used to repress the female through creating strong notions of hierarchy. Indian women become the victims of that process. They are compelled to be muted. Their voices do not get an opportunity to speak out of the women's problems and needs. Their desires always get lost before the grand narratives of patriarchy, even the national history and narrative rarely recognize the major contribution of the females in the texts or document. Whenever the woman is portrayed, she is put in the second position below the man. She is always kept silent. Identifying this issue, Indian critic and feminist Gayatri Chakravorty Spivak asks - can the subaltern speak? in her essay 'Can the Subaltern Speak?'. To answer this question, she says: “There is no space from which the sexed subaltern subject can speak ... The subaltern cannot speak" (Spivak 103-104). The reason, Spivak shows, is that Indian woman is always given a label of Sati or good wife. "Sati as a woman's proper name is in fairly widespread use in India . . . Naming a female infant 'a good wife' has its own proleptic irony ..." (102). By giving a great woman portrayal to the Indian woman, the grand narrative of patriarchy stereotypes the status of woman in the society. Through this, a boundary is imposed on the Indian women's lifestyle and so-called freedom. While examining the power and position of Indian women, Spivak observes a fragile state:

Between patriarchy and imperialism, subject-constitution and object-formation, the figure of the woman disappears, not into a pristine nothingness, but into a violent shuttling which is the displaced figuration of the 'third-world woman' caught between tradition and modernization. (102)

So, the position of the 'third world woman' is in-between 'patriarchy and imperialism, subject-construction and object-formation and tradition and modernization'. Spivak's discovery seems correct if we look at the nature and rage of the characters Nanda Kaul, Ila Das and Raka. The three female characters are in shaky and disturbing positions although they are from different generations. For instance, Nanda Kaul wants to be isolated. Her attitude to the other people reveals her aloofness. Now a question arises here: does she want to escape? Then, from 
whom and from what? In the last page, the causes come out when she gets the death news of Ila Das from the Police inspector. The reaction of Nanda Kaul shows that her whole life is full of lies. Her husband lies to her; her children cannot understand her nature and herself. She pretends that she has a good relation with her husband even though he has not loved his wife because of his extra marital affair with another Christian woman. She lies to Raka by telling all the fairytale like stories about her husband and his treatment towards her, and her father's travels. The pretensions create dissatisfaction. It is evident that the disappointments of Nanda Kaul are suppressed. The death of Ila Das, who was Nanda Kaul's only friend, helps Nanda Kaul to discover the tragedy of her life with a new perspective. Her realization is tremendous which sparks her inner rage:

It was all a lie, all. She had lied to Raka, lied about everything. Her father had never been to Tibet - he had bought the little Buddha from a traveling pedlar. They had not had bears and leopards in their home, nothing but overfed dogs and bad-tempered parrots. Nor had her husband loved and cherished her and kept her like a queen - he had only done enough to keep her quiet while he carried on a lifelong affair with Miss David, the mathematics mistress, whom he had not married because she was a Christian but whom he had loved, all his life loved. And her children - the children were all alien to her nature. She did not live here alone by choice - she lived here alone because that was what she was forced to do, reduced to doing. All those graces and glories with which she had tried to captivate Raka were only a fabrication: They helped her to sleep at night, they were tranquillizers, pills. She had lied to Raka. And Ila had lied, too. Ila, too, had lied, and tried. (Anita 145)

Beside Nanda Kaul, Ila Das and Raka also play a crucial role in the novel. Ila Das is Nanda's bosom friend and a social worker. She attempts to change the lifestyle and world of the female by stopping the early marriages and advising the women to go to the hospital for health treatment in the villages. But the local priest does not consider her activities as good. He motivates the male villagers not to allow their women to listen to Ila Das. He also influences them to work against her. For these reasons, Ila Das struggles against social barriers. But she does not take any attempt to resist the anti-forces. Still then, she is raped and killed in a dark night. The 
villagers find her dead body beside the road and later police recovers her body. The fate of Ila Das shows the ultimate destiny of a woman (which is sexual humiliation or death) if she goes against the patriarchy's sermon. This also indicates the transformation of the experience of Indian women as well as India as a country. Although the Indian women are surrounded by patriarchal ideology, a change has occurred in the construction of female subjectivity. Nanda Kaul's sufferings are suppressed and rage is raised in the mind but Ila Das tries to prevent those. Nanda Kaul's experience of suppressed rage and Ila Das' experience of violence, both physical and psychological, show an elevation to construct a female subject. Unfortunately, the formation of the female self cannot get the full face because of her inherited volatile present position and power which are not only fragmented but also distorted. The violent inner and external experiences affect Raka, Nanda Kaul's great grand daughter. It is true that Raka does not observe the incidents of female struggles but she automatically senses and inherits those through her inseparable relation with her root. Her future female identity is constructed based on her great-grand mother's fabricated stories about the treatment of patriarchy (father, husband and children) on females (mother, wife and children). Raka realizes the falsehood but does not protest. She also lies and hides herself in falsehood to keep the relation intact. But she falls into an identity crisis gradually because of inherited fragmented social status of India woman. It can be said that Raka represents the modern generation of modern India or new India. If we concentrate on the diagram below, the sequential development of the Indian women will be displayed. 

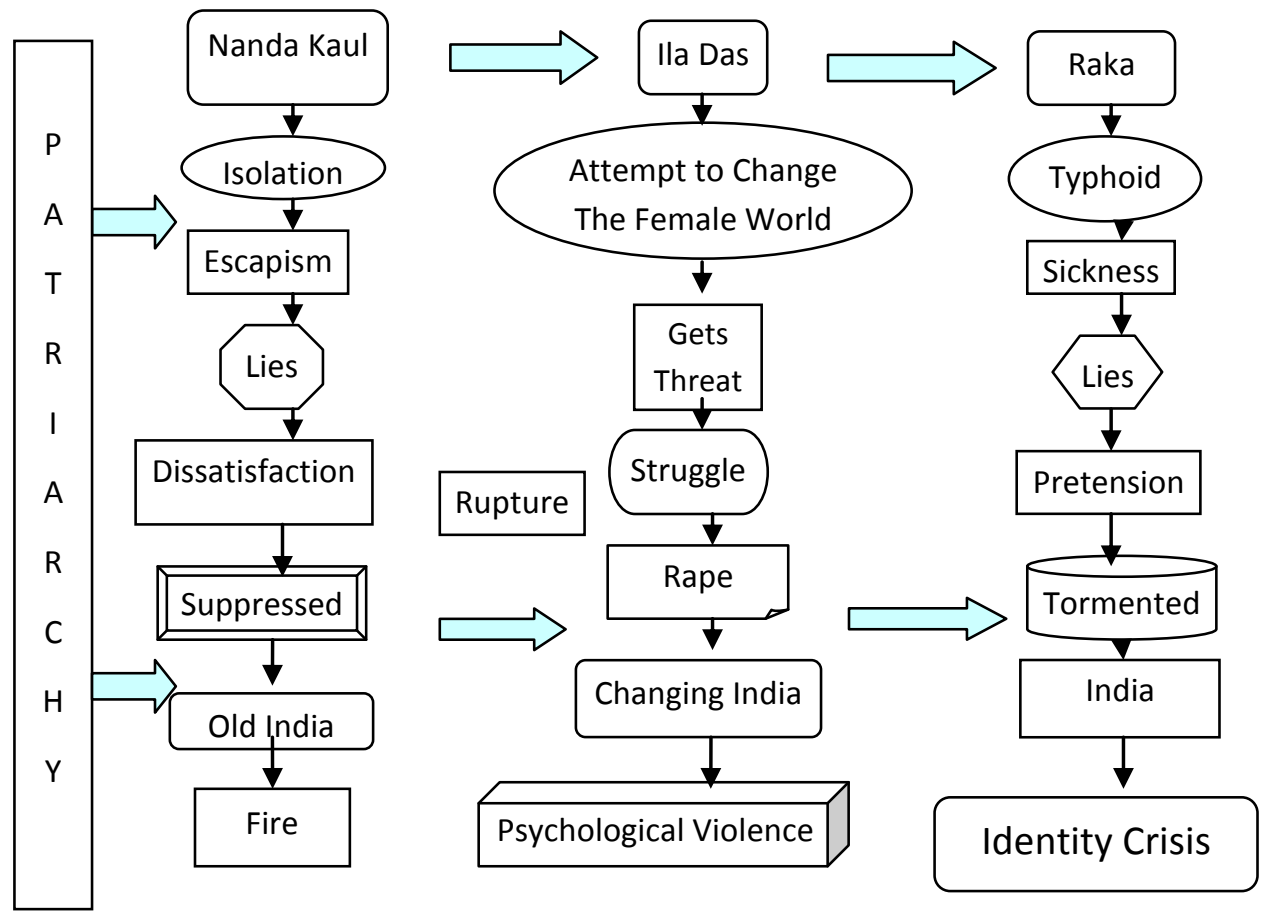

Figure 1: The process of patriarchal domination on Indian women generation after generation and their experience which has extended resonance from individual to nation.

Up to this, we have seen - how the psychic violence develops in stages in its highest pick. After Fire on the Mountain's psychic violence, let us analyze Tony Morrison's The Bluest Eye.

It is notable to observe the universal similarities of female experience in the realm of cultural, historical and racial differences as well as diversities between these two novels. While Anita Desai's Fire on the Mountain presents a repressed female story, Toni Morrison's The Bluest Eye portrays the female characters more openly and intensively. The protagonists of the novel are Pauline and Pecola, who are mother and daughter in relation. Although Pauline and Pecola are from 
different generations, they get the same kind of realistic experiences. Morrison's The Bluest Eye shows the American Black female's captive situation where she has to bear the torture coming from the White race. Here, the Black community plays a significant role to construct the female subject. The Black community and Black individual are intertwined. The Black female individual struggles to have an appropriate physical and psychological growth, even the Black male suffers from the same problems. But females are vulnerable because of their most inferior position in the society. With this, the inhuman and horrible slave history is added in the mind which intensifies the psychological torments. The story focuses on the poor Black girl whose growth is disturbed in a hostile environment. Brutality makes her life miserable. When it is time to play and have a beautiful life under her parent's protection, she is physically and later psychologically humiliated by her own parents. Pecola is raped by her father. When she tells about the sexual abuse to her mother Pauline, Pauline beats her up. She does not even get the minimum sympathy from her mother. Moreover, the neighbours create an extra mental pressure by suggesting that Pecola should be taken to the doctor for check up whether she became pregnant or not. The reaction of Pecola is really touchy.

"Miss Dunion ... Said that Mama should take me to the doctor, because I might be ruined, and Mama started screaming all over again."

"At you?"

"No. At Miss Dunion."

"But why were you crying?

"I don't want to be ruined!" (Morrison 78)

Significantly, the sexuality and pregnancy are seen as the 'ruin' for a Black woman. If a girl experiences sexual intercourse outside marriage and gives birth to a child, she is considered as a doomed person without any hope for the future. She is also seen as a breeding stock. Sexuality is a curse for a Black woman. Here, to describe the position of woman and sexuality, the feminist critic Nancy Chodorow in her essay 'Feminism and Psychoanalytic Theory' states:

... women were trapped through their own reproductive anatomy, the objectification of their bodies, the mothering relation or the marriage relation, 
compulsory heterosexuality, the cultural or ideological construction of 'woman', location in the domestic sphere, or association with nature. (182)

Sarcastically, sex and marriage are positioning a woman as a sex slave. With sexual torture and pregnancy, another concerning matter arises. The concern about the unborn child is about his/her identity as well as the future. Pecola's child is a product of her father, Cholly. At the same time, the child is Pecola's brother and son in relation. So the complex relations and situations make Pecola's existence as a woman very miserable. Although Pecola gives birth to a dead boy, the annoying relation and cruel reality destroy the structured ideology and institution of the society. It frustrates the future of both Black man and woman because the black man is the bastard child of a humiliated mother. Though the bastard child is dead (physically and psychologically) from its birth, it has less right compared to an animal to live in this world. Symbolically, this reminds one of the time of slavery. And Pecola, who is from post slavery world, still inherits and carries the curse of violence.

After the problem of sexuality, there is other important aspect in The Bluest Eye. And that is - the fascination for the White Beauty. The Black woman always feels jealous of the White woman's beauty. She dreams to have the white skin, blue eyes and blond hair. At the same time, she desires those because a power play is involved there. She wants to conquer and occupy the position and power of the white woman, in the way Black colonized man wants to take the possession of the White colonizer's position and power. The concept of this power relation is discovered by the Indian theorist Homi K. Bhabha in The Location of Culture. There, he writes: ". . . there is no native who does not dream at least once a day of setting himself up in the settler's place. It is always in relation to the place of the 'Other' that colonial desire is articulated . . ." (44). Although the White woman is subordinate to the White man, she is superior to the Black man and woman. The intensity for being White can be further understood if we look at the Black man's desire to be White in French educated Algerian Psychiatrist Frantz Fanon's book Black Skin White Mask where Fanon comments:

What does the black man want? 
. . . the black man who wants to turn his race white is as miserable as he who preaches hatred for the whites. (8-9)

So, Pecola desires to have the bluest eye not only from the fascination to White beauty but also from the strong attraction to White power. Ironically, the apparent meaning for desiring the bluest eye is nothing but a fascination. But the deeper meaning is - Pecola wants that because she wants to dominate or take revenge on the Black man's violence. And it is possible to go against the violence of males only by getting the bluest eye of white power. A suppressed desire is revealed through this.

"I can't go to school no more. And I thought maybe you could help me."

"Help you how? Tell me. Don't be frightened."

"My eyes."

"What about your eyes?"

"I want them blue." (Morrison 138)

Everyone can understand that Pecola is running after an illusion but it gives her a hope to life in this cruel world. On the other hand, Pecola's mother, Pauline, also loves to stay and work in the house of Fisher family. She wants to be the ideal servant' (Morrison 99) because she is dominated by her husband, Cholly, and with breaking the patriarchy, she wants to remove her loneliness. Her married life is not happy. Before her work, she is continuously neglected by her husband who is busy with his friends and orks. This makes Pauline bored. Pauline turns into a sex slave and breeder. The social and cultural boundaries compel her to surrender before the patriarchy. The evidence of her situation can be found in the lines below of the novel The Bluest Eye:

Cholly was kindness, still, but began to resist her total dependence on him. They were beginning to have less and less to say to each other. He had no problem finding other people and other things to occupy him-men were always climbing the stairs asking for him, and he was happy to accompany them, leaving her alone. (92)

The psychological and physical violence disturbs Pauline's life. The violence does not allow her to construct a proper identity. The changing of female 
generations is worsening the condition of women. We see rage and fragmented subject who is the outcome from Pauline's generation and despair comes out from Pecola's generation. It is obvious that Pecola and Pauline are fighting against the Black patriarchy but it is very difficult to ignore the domination of White people on Black man. Here, the victim of that domination is Cholly who is also sexually abused by two white men. The incident and bad behaviour of his father toward him causes psychological distortion. Later this distortion turns into violence. Although it is cruel to rationalize the incidents, unfortunately that is the reality. The below graph will help us to understand the relation, complexity and violence to construct a Black woman's subjectivity.

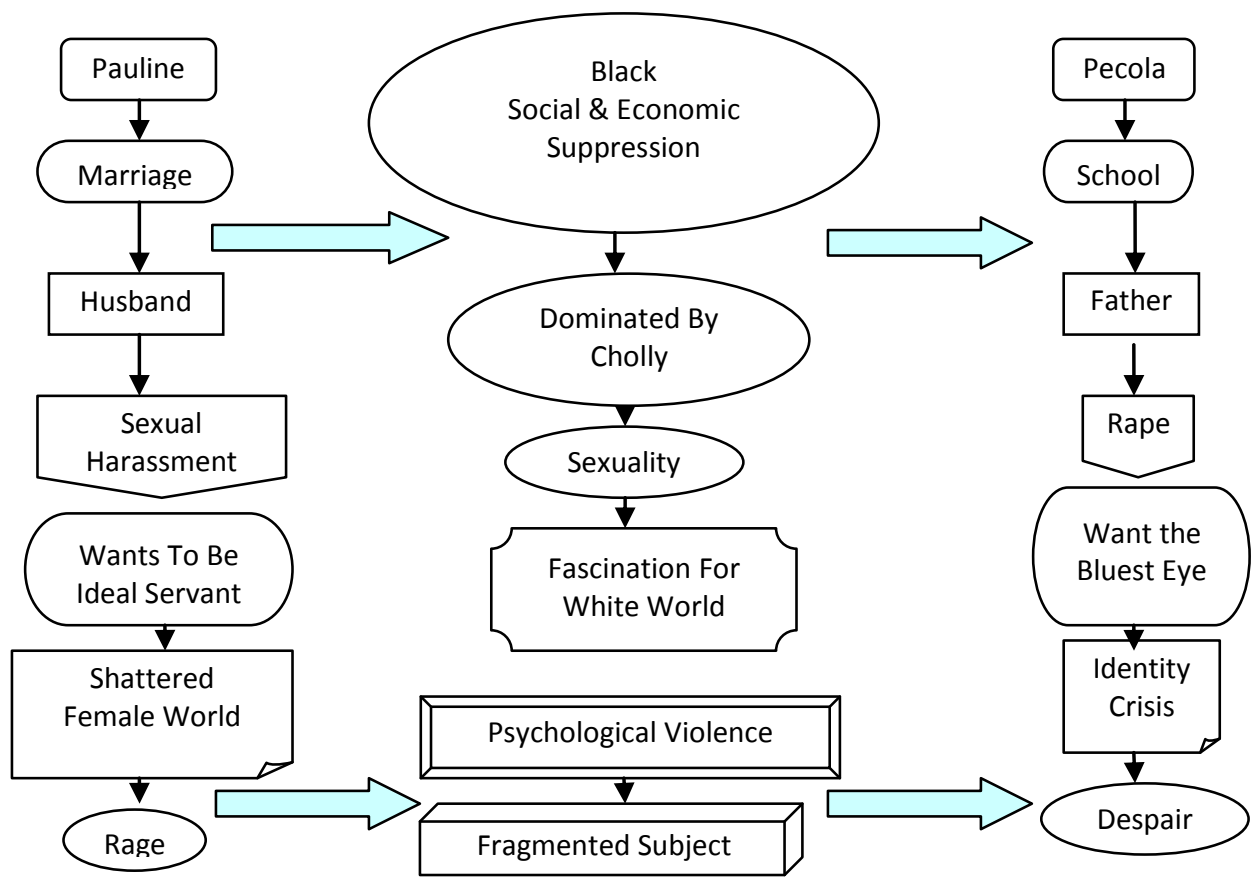

Figure 2: Cycle of Black women's horrible experience and their fight against violence. 
Toni Morrison's The Bluest Eye displays the growth of a female subject facing a lot of complications. The characters are apparently free but actually they are like slaves. Apparently, Black community and Black individuals are free from direct White domination but the Black female world does not get the opportunity to taste the freedom. The Black women remain in the dark as they were before at the time of slavery. For instance:

They never seem to have boyfriends, but they always marry. Certain men watch them, ... and know that if such a girl is in his house, he will sleep on sheets boiled white, hung out to dry on juniper bushes, and pressed flat with a heavy iron. There will be pretty paper flowers decorating the picture of his mother, a large Bible in the front room. They feel secure. They know their work clothes will be mended, washed, and ironed on Monday ... Her hips assure them that she will bear children easily and painlessly. And they are right ... But the men do not know these things. Nor do they know that she will give him her body sparingly and partially. He must enter her surreptitiously, lifting the hem of her nightgown only to her navel. He must rest his weight on his elbows when they make love, ostensibly to avoid hurting her breasts but actually to keep her from having to touch or feel too much of him. (Morrison 65)

From the above quotation, it can be understood how women fall into a stereotypical world where roles of women are well defined. Morrison points out how men enslave the women in the household. She discovers the systematic process of domination (psychological and physical) on the Black women.

It is evident that the process of Othering and stereotyping the woman is attacked by both Anita Desai and Toni Morrison. Morrison's exhibition of woman echoes the colonial binary concept - self and other. In the colonial set up, the Black woman is projected as the other but Morrison shows the whole story from the other's perspective in the postcolonial as well as post slavery era. Simultaneously, Desai also demonstrates the so-called third world woman as the Other in both colonial and postcolonial structural models. It will be very difficult to measure the power and position between an American Black woman and an Indian woman. But the target of Nanda Kaul, Ila Das, Raka from Fire on the Mountain and Pecola, Pauline, 
Claudia from The Bluest Eye is to form a female identity or subject in their respective realms. The diagram below will show the relation of women with the colonization and the present world. With that, it will also point out the different positions of different women in different situation. Even though, we have essentialized as well as categorized transnational cultures of women to show the female struggle against the common dominator, each and every path of fighting is different and unique. The variation of women's experience helps to build up the world of women, where violence is revealed their discourses of language and female subject is constructed based on those revolutions.

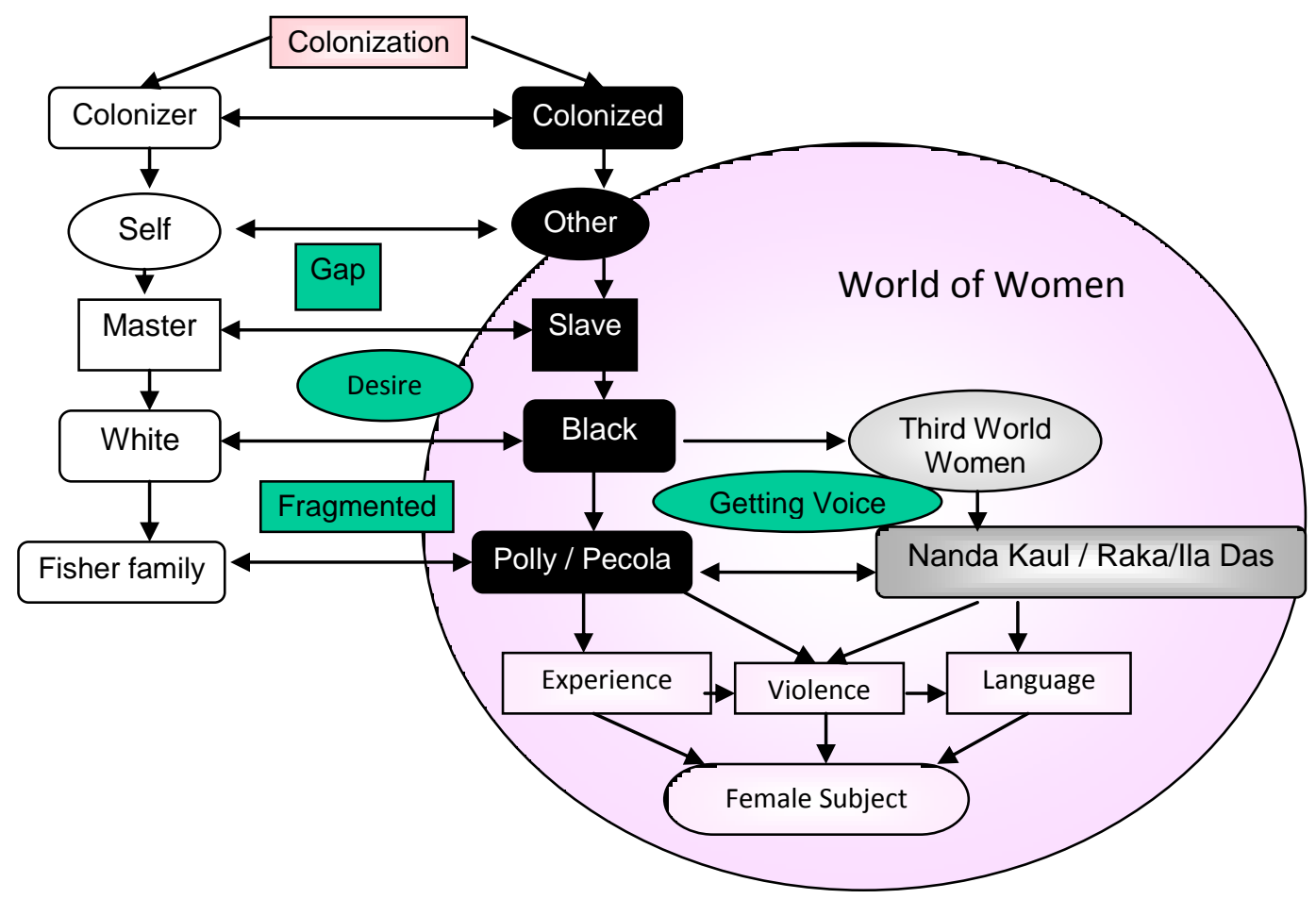

Figure 3: Place of women of different locations who are experiencing the same issues in the colonial framework. 
The crucial development in world of feminism is that women are getting their voices to speak out their experiences and violent struggle in feminist discourse. To talk about the language in The Bluest Eye, Morrison states:

My choices of language (speakerly, aural, colloquial), my reliance for full comprehension on codes embedded in black culture, my effort to effect immediate co-conspiracy and intimacy (without any distancing, explanatory fabric), as well as my attempt to shape a silence while breaking it are attempts to transfigure the complexity and wealth of Black American culture into a language worthy of the culture. (172)

Although Anita Desai does not speak about the emerging of a new discourse of language in her novel, she talks about her style of writing which reveals the state of the human psyche among flashes of insight, destruction of their dreams and a distortion of reality.

While writing, I follow my instinct, I follow flashes of insight, I veer away from and even fight anything that threatens to distort or destroy this insight, and somehow come to the end and look back to see the pattern of footprints on the sand ... A story imposed from the outside simply destroys their life, reduces them to a string of jerking puppets on a stage whatever action there is must be part of the integral whole composed of the human psyche, the human situation, the outer and inner rhythms. (Rao and Rajeshwar 153)

Both Fire on the Mountain and The Bluest Eye deal with female experiences and subject construction although the background, circumstance, race, ideology and perspectives are different. There are several universal female experiences which are the same in both the novels - patriarchy, sexual abuse, violence, suppressed rage, sickness, alienation, isolation, mystery, physical domination, psychological crisis, ideological domination, lies, pretension, identity crisis, mental disorder, struggling, fire, destiny, fragmented subject etc. In this paper, my aim to examine the experience of women in transnational cultures is achieved because the investigation is to see the transnational women's struggles to earn their rights and freedom. And it is found that the goal of women of different cultures is the same and that is breaking the patriarchy's physical and psychological domination and creating a 
new identity with different languages, discourses, notions, social uninterrupted and secured growth, meaningful destiny and stabilized mental strength. Although I have examined the two different novels, the kinds of struggle are different but the patterns of sufferings are alike. Anita Desai's Fire on the Mountain is narrated with the Indian Hindu hilly village society in the background. In contrast, Toni Morrison's The Bluest Eye is portrayed in the background of the American Black Christian community. Having this huge difference, both the novelists try to construct the female subject under the pressure of male domination. In both the cases, sexual and psychological violence erupt from the suppressed women like the volcano. Interesting to observe as a reader, both the plots of the novels are described from the woman's self perspective which re-identifies the causes of the woman's psychic violence. 


\section{Works Cited}

Bhabha, Homi K. The Location of Culture. London: Routledge, 1994. Print.

Chodorow, Nancy. 'Feminism and Psychoanalytic Theory,' Feminisms. Ed. Sandra Kemp and Judith Squires. New York: Oxford University Press, 1997. 182 - 188. Print.

Coward, Rosalind, et al. The New Feminist Criticism: Essays on Women, Literature and Theory. Ed. Elaine Showalter. London: Viraco Press Limited, 1986. 3 - 17. Print.

Desai, Anita. Fire on the Mountain. London: Vintage, 1999. Print.

Fanon, Frantz. Black Skin White Mask. New York: Grove Press Inc, 1967. Print.

Moi, Toril. 'Feminist, Female, Feminine.' Feminisms. Ed. Sandra Kemp and Judith Squires. New York: Oxford University Press, 1997. 246 - 250. Print.

Morrison, Toni. The Bluest Eye. London: Vintage, 1999. Print.

Prasad, Amar Nath. 'A Brief History of Indian Women Novelists in English.' Indian Women Novelists in English. Ed. Amar Nath Prasad. New Delhi: Atlantic Publishers and Distributors, 2001. 1 - 18. Print.

Rao, P. Mallikarjuna, and M. Rajeshwar, eds. Indian Fiction in English. New Delhi: Atlantic Publishers and Distributors, 1999. Print.

Spivak, Gayatri Chakravorty. 'Can the Subaltern Speak?' The Postcolonial Studies Reader. Ed. Bill Ashcroft, Gareth Griffiths and Helen Tiffin. London: Routledge, 1995. 24 - 28. Print. 